\title{
Kajian Komponen Angin Zonal dan Meridional sebagai Prekursor Penentu Awal Musim di Palembang Serta Pengaruh ENSO dan IOD Terhadap Variasinya
}

\section{Study of Zonal and Meridional Wind Components as Precursors for Onset of Season Determinants in Palembang and the Effects of ENSO on Variations}

\author{
Presli Panusunan Simanjuntak ${ }^{1^{*}}$, Dinda Rosyia ${ }^{2}$, Nabila Kendita ${ }^{3}$, Dhiyaul Qalbi ${ }^{4}$, Agus Safril ${ }^{5}$ \\ 1,2,3,4,5)Program Studi Klimatologi \\ Sekolah Tinggi Meteorologi Klimatologi dan Geofisika \\ Jl. Perhubungan I No. 5, Pondok Aren, Kota Tangerang Selatan, Banten 15221, Indonesia \\ email: ${ }^{* 1}$ preslisimanjuntak06@gmail.com
}

\begin{abstract}
DOI;
10.30595/jrst.v5i1.6635

ABSTRAK

Histori Artikel:

Diajukan:

$28 / 05 / 2020$

Diterima:

$04 / 03 / 2021$

Diterbitkan:

$27 / 03 / 2021$

Prediksi awal musim merupakan informasi yang sangat dibutuhkan oleh berbagai sektor kehidupan.Terdapat berbagai macam metode yang dapat digunakan untuk memprediksi awal musim, salah satunya dengan melihat perubahan arah dan kecepatan dari komponen angin. Hal tersebut didukung oleh pemahaman bahwa angin membawa berbagai zat di atmosfer yang termasuk di dalamnya adalah uap air. Transport uap inilah yang berperan menentukan intensitas dan periode hujan di suatu wilayah. Data acuan yang digunakan adalah data curah hujan bulanan dari Stasiun Klimatologi Palembang. Adapun data penginderaan jauh yang digunakan adalah data angin zonal dan meridional pada lapisan 850 mb yang diperoleh dari ECMWF. Periode yang dikaji adalah Januari 1987 hingga Desember 2017. Data yang diperoleh kemudian dipilih dan di plot kedalam beberapa grafik dengan latar belakang kondisi yang berbeda. Seperti periode normal, periode ENSO kuat dan periode IOD. Hasil analisis menunjukkan bahwa angin zonal dan meridional di Palembang tidak terlalu mempengaruhi awal musim hujan. Sedangkan untuk awal musim kemarau, angin zonal dan meridional tampak lebih berpengaruh. Hal ini disebabkan adanya lag antara keduanya yang mendukung angin zonal dan meridional lapisan $850 \mathrm{mb}$ dari permukaan untuk dijadikan prekursor awal musim kemarau di Palembang.
\end{abstract}

Kata Kunci: awal musim, zonal, meridional, enso,

\begin{abstract}
Onset of season prediction is information that is needed by various sectors of life. There are various kinds of methods that can be used to predict the start of the season, one of them by looking at changes in direction and speed of the wind component. This is supported by the understanding that wind carries various substances in the atmosphere including water vapor. Steam transport is what plays a role in determining the intensity and period of rain in an area. The reference data used is monthly rainfall data from Palembang Climatology Station. The remote sensing data used are zonal
\end{abstract}


and meridional wind data on the $850 \mathrm{mb}$ layer obtained from ECMWF. The period examined is January 1987 to December 2017. The data obtained are then selected and plotted into a number of charts with different background conditions. Like normal periods, strong ENSO periods and IOD periods. The analysis showed that zonal and meridional winds in Palembang did not significantly affect the start of the rainy season. Whereas for the beginning of the dry season, zonal and meridional winds appear to be more influential. This is due to the lag between the two that support the zonal wind and the $850 \mathrm{mb}$ layer meridional from the surface to be a precursor to the beginning of the dry season in Palembang

Keywords: onset of season, zonal, meridional, enso

\section{PENDAHULUAN}

Terdapat beberapa cara yang dapat dilakukan dalam memprediksi awal musim hujan $(\mathrm{AMH})$. Cara sederhana dan paling umum digunakan adalah dengan menyusun pola distribusi curah hujan sesuai periode klimatologis (rata-rata 30 tahun) dan kemudian dibuat grafik batang. Menurut BMKG, banyak cara yang dilakukan para ahli dalam memprediksi AMH. Cara yang paling umum dilakukan adalah dengan mengelompokkan pola distribusi curah hujan secara klimatologis (rata - rata 30 tahun) dan kemudian dibuat grafik batang (bar chart). Menurut BMKG, penetapan AMH jika jumlah curah hujan mencapai $50 \mathrm{~mm}$ atau lebih dalam satu dasarian yang diikuti oleh beberapa dasarian dengan minimal diikuti oleh dua dasarian berturut-turut (BMKG,2013).

Angin adalah udara yang bergerak dari daerah bertekanan udara tinggi ke daerah yang bertekanan udara lebih rendah (Kato dkk., 1998). Angin horisontal terbagi menjadi dua arah yaitu zonal dan meridional. Angin zonal merupakan sirkulasi angin yang berhembus dengan arah timur-barat disebut juga sirkulasi Walker, sedangkan angin meridional merupakan sirkulasi angin yang berhembus dengan arah utara-selatan disebut juga sirkulasi Hadley. Posisi Indonesia menyebabkan wilayahnya dipengaruhi oleh sirkulasi Hadley dan sirkulasi Walker, dua sirkulasi yang sangat mempengaruhi tingkat variabilitas hujan di Indonesia (Aldrian dkk., 2007).

Sebagian besar di wilayah Indonesia, angin zonal baratan umumnya terjadi saat musim hujan dengan kecepatan dengan kecepatan 0 sampai 10 meter/detik, sedangkan angin zonal timuran dominan terjadi saat musim kemarau dengan kecepatan 0 sampai 10 meter/detik. Untuk angin meridional yang bergerak dari utara ke selatan atau sebaliknya, pada saat musim hujan umumnya kecepatannya 0 sampai 10 meter/detik sedangkan saat musim kemarau kecepatannya menurun sekitar 0 sampai 5 meter/detik. Proses gerakan angin ini akan mengalami kecepatan bervariasi dan berfluktuasi secara dinamis (Sandy, 1987).

Namun dalam pergerakannya, angin zonal juga mengalami pelemahan dan penguatan. Perubahan dalam angin zonal terkait dengan $E l$ Niño-Southern Oscillation (ENSO), yang mendorong perubahan besar dalam curah hujan (Ropelewski dan Halpert, 1989; Allan dkk., 1996; Power dkk., 1999). ENSO merupakan sebuah interaksi laut atmosfer yang berpusat di wilayah ekuator Samudra Pasifik (Aldrian, 2008). Komponen lautan dari ENSO adalah El Nino dan La Nina, sedangkan komponen atmosfernya adalah Southern Oscillation (Trenberth, 1997). Pada saat berlangsung El Nino, terjadi penguatan angin baratan di Pasifik barat daerah ekuator mulai dari sebelah utara Irian hingga Pasifik Tengah (Trenberth dan Sea, 1987, Harrison dan Larkin, 1998). AMH musim hujan di Jawa dan sebagian Sumatera lebih lambat dibandingkan dengan rata ratanya ketika terjadi El Nino dan lebih cepat dari rata-ratanya ketika terjadi La Nina (Hamada, 1995). Fenomena ENSO yang terjadi dapat mempengaruhi angin zonal yang kemudian berdampak pada curah hujan serta awal musim di sebagian wilayah di Indonesia.

Selain ENSO, penyimpangan iklim lainya yang dapat berpengaruh pada pergerakan sirkulasi angin adalah IOD (Indian Ocean Dipole), terdapat dua fase IOD yaitu IOD positif $(+)$ dan IOD negatif (-) (Saji dkk.,1999). IOD (+) terjadi saat wilayah pantai barat Sumatera bertekanan tinggi, sementara sebelah timur pantai benua Afrika bertekanan rendah sehingga terjadi aliran udara dari bagian barat Sumatera ke bagian timur Afrika yang mengakibatkan pembentukkan awan-awan konvektif di wilayah Afrika dan menghasilkan curah hujan di atas normal. Sebaliknya, di wilayah Barat Sumatera terjadi kekeringgan setelah massa uap airnya gagal diturunkan sebagai hujan. Sebaliknya, pada saat IOD (-), wilayah barat Sumatera termasuk Sumatera Barat mengalami surplus curah hujan 
dan wilayah timur Afrika mengalami kekeringan. (Martono, 2017)

Informasi curah hujan dan awal musim sangat penting untuk berbagai sektor, khususnya pertanian dan perkebunan (Ulfah, 2015) selain itu informasi curah hujan dan awal musim penting juga untuk mitigasi dalam kebencanaan hidrometeorologi seperti banjir dan kekeringan (Harijanto,2012)

Mengingat pentingnya informasi awal musim bagi berbagai sektor studi ini mengambil wilayah Palembang sebagai daerah analisis dengan kondisi musimnya dipengaruhi oleh angin monsoon. Studi dilakukan untuk mengetahui pola komponen angin zonal dan meridional di lapisan $850 \mathrm{mb}$, serta respon angin terhadap curah hujan dengan melibatkan periode variasi iklim global seperti ENSO terkait dengan dimulainya awal musim.

\section{METODE PENELITIAN 2.1 Data}

Kajian ini menggunakan data angin zonal dan meridional bulanan pada lapisan $850 \mathrm{mb}$ di wilayah Indonesia luaran model ECMWF dengan resolusi spasial $0.125^{\circ} \times 0.125^{\circ}$ periode 1987 2017. Selain itu, digunakan pula data curah hujan bulanan untuk periode yang sama diperoleh dari Stasiun Klimatologi Palembang.

Selain mengetahui normal perilaku angin zonal dan meridionalnya, kajian ini juga membandingkan hal yang sama namun selama periode kejadian El Nino, La Nina, IOD positif dan IOD negatif untuk mengetahui respon angin zonal dan meridional terhadap variasi iklim skala global tersebut. Tahun IOD dipilih dimana indeks ENSO normal, hal ini dilakukan untuk melihat pengaruh masing-masing secara lebih objektif.

\subsection{Metode}

Parameter yang dikaji adalah komponen angin zonal dan meridional. Data angina zonal dan meridional bulanan yang diperoleh meliputi seluruh wilayah Indonesia. Ekstraksi menggunakan perangkat lunak BEAM dilakukan sehingga diperoleh data di titik kajian. Data inilah yang kemudian digunakan selama pengolahan.

Dominansi normal arah angin ditentukan berdasarkan frekuensi kejadian terbanyak selama periode 1987-2017. Kecepatan angin bulanan diperoleh dengan mereratakan parameter yang sama dari arah yang dominan saja. Penentuan arah dan kecepatan angin berlaku baik untuk komponen zonal maupun meridionalnya. Tanda positif bagi angin zonal merujuk pada angin baratan sedangkan negatif berarti timuran. Tanda positif bagi angin meridional berarti angin dari arah selatan dan negatif dari utara. Komponen angin zonal dan meridional ini kemudian dibandingkan dengan kondisi curah hujannya. Sama halnya dengan kecepatan, normal curah hujan bulanan diperoleh dengan mereratakan curah hujan per bulan pada periode normal 1987-2017. Perlakuan ini, baik untuk parameter angin dan curah hujan bulanan, dilakukan pada data periode normal (1987-2017) dan kejadian ENSO kuat dan IOD (+) dan IOD (-) sehingga dapat diketahui kemungkinan adanya pengaruh aktivitas ENSO dan IOD terhadap variasi angin zonal dan meridional di Palembang. Penentuan magnitud ENSO kuat berdasarkan indeks Nino 3.4 (ONI) yaitu lebih (kurang) dari 1.5 (-1.5) untuk El Nino (La Nina) menurut definisi BMKG (Yananto \& Sibarani, 2016).

Pada penelitian ini digunakan kriteria BMKG dimana musim kemarau terjadi saat curah hujan bulanan di bawah $150 \mathrm{~mm}$ dan musim kemarau dimulai saat curah hujan bulanan berada di atas 150mm (BMKG,2013)

\section{HASIL DAN PEMBAHASAN}

\subsection{Periode Normal (1987-2017)}

Palembang termasuk kedalam daerah ZOM dimana terdapat perbedaan yang jelas antara musim hujan dan musim kemarau. Curah hujan normal di Palembang memiliki rentang antara 80 $\mathrm{mm}$ hingga $360 \mathrm{~mm}$.

Awal musim hujan wilayah Palembang dimulai pada bulan Oktober dan berlangsung hingga bulan Mei. Sedangkan awal musim kemarau dimulai pada bulan Juni dan berlangsung hingga September seperti dijelaskan pada Gambar 1. Berdasarkan Gambar 1 terdapat hubungan yang berkebalikan antara angin zonal dan meridional. Angin zonal merupakan angin yang bergerak dengan arah timur-barat, sedangkan angin meridional bergerak dengan arah utara-selatan. Angin zonal positif menandakan gerak angin ke arah timur, sedangkan angin meridional negatif menandakan gerak angin ke arah utara. 


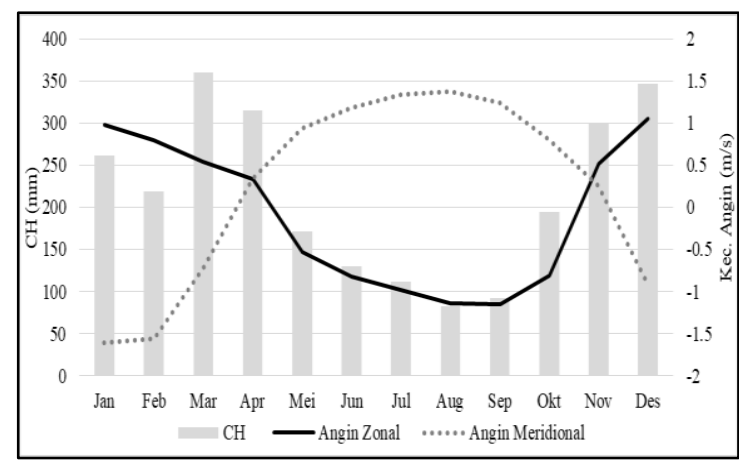

Gambar 1. Angin Zonal dan Meridional dan Curah Hujan Bulanan pada Periode Normal

(1987-2017)

Pola angin zonal lapisan $850 \mathrm{mb}$ menunjukkan pergerakan angin baratan yang dimulai pada bulan November dengan kecepatan rata-rata $0,5 \mathrm{~m} / \mathrm{s}$. Angin baratan mengalami peningkatan kecepatan hingga bulan Januari mencapai $1,0 \mathrm{~m} / \mathrm{s}$. selanjutnya diikuti dengan pelemahan angin baratan pada bulan Februari hingga April yang mencapai kecepatan terendah. Pergerakan angin timuran mulai terlihat pada bulan Mei dan semakin menguat hingga bulan September yang mencapai kecepatan $1,2 \mathrm{~m} / \mathrm{s}$. Pergerakan angin baratan baru terlihat setelah dimulainya musim hujan yaitu di bulan Oktober. Sedangkan angin timuran menunjukkan adanya respon lag satu bulan terhadap curah hujan, dimana awal musim kemarau terjadi satu bulan setelah angin timuran masuk yaitu di bulan Juni.

\subsection{Periode El Nino Kuat}

Analisis pola angin zonal dan meridional pada periode El Nino kuat dilakukan dengan mengambil tahun kejadian 1997. Selanjutnya digunakan indeks ONI yang merupakan parameter utama NOAA untuk mengelompokkan kejadian ENSO.

Pada saat ONI bernilai positif berarti suhu muka laut di Pasifik timur lebih hangat dari biasanya. Jika ONI positif mencapai $>0,5$ hingga 1 maka dinyatakan sebagai El Nino lemah. El Nino kategori sedang terjadi pada indeks 1-1,5, sedangkan kategori El Nino kuat terjadi pada nilai indeks 1,5 - 2. El Nino sangat kuat terjadi jika indeks ONI melebihi 2,0.

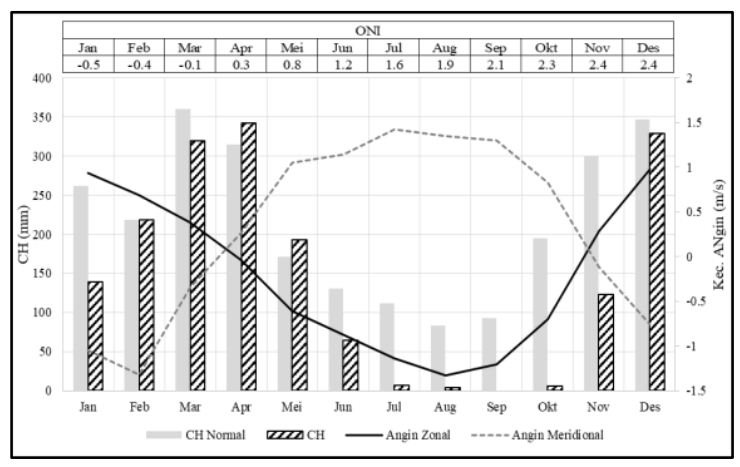

Gambar 2. Angin Zonal dan Meridional dan Curah Hujan Bulanan pada Periode El Nino Kuat (1997)

Indeks ONI pada tahun 1997 berada pada rentang -0,5-2,4 dengan indeks terendah pada bulan Januari dan indeks tertinggi pada bulan November. Nilai maksimum ONI yaitu 2,4 menunjukkan terjadinya kejadian El-Nino sangat kuat pada tahun ini. Respon curah hujan terhadap indeks ONI menunjukkan adanya penurunan curah hujan terhadap periode normal, utamanya di bulan Juni hingga Desember, yaitu ketika fase El Nino sedang hingga kuat.

Pola angin zonal pada periode tahun 1997 mencapai kecepatan maksimum pada bulan Agustus sebesar $1,33 \mathrm{~m} / \mathrm{s}$ dan kecepatan minimum terjadi pada bulan April sebesar 0,04 $\mathrm{m} / \mathrm{s}$. Pola angin zonal menunjukkan pergerakan angin timuran yang dimulai pada bulan Mei dan berlangsung hingga bulan Oktober. Hal ini mengindikasikan aktifnya angin monsoon timur yang membawa musim kemarau bagi wilayah Palembang. Meskipun demikian, berdasar pada kriteria awal musim dari BMKG, wilayah Palembang baru mengalami musim kemarau di bulan Juni hingga November. Hal ini menunjukkan adanya lag +1 bulan antara angin zonal dan awal musim kemarau dimana awal musim terjadi satu bulan setelah masuknya angin timuran. Angin baratan mulai tampak di bulan November. Hal ini menunjukkan adanya lag +1 bulan antara masuknya angin baratan terhadap awal musim hujan. Dimana awal musim hujan dimulai satu bulan setelah angin baratan masuk yaitu pada bulan Desember.

Pola angin meridional pada periode tahun 1997 mencapai kecepatan maksimum pada bulan Juli sebesar 1,42 m/s dan kecepatan minimum terjadi pada bulan November sebesar 0,11 m/s. Angin meridional positif yang bergerak dari selatan ke utara terjadi pada bulan April hingga Oktober. Hal ini menunjukkan adanya lag +2 
terhadap awal musim kemarau yang jatuh pada bulan Juni dan lag +1 bulan terhadap akhir musim kemarau di bulan November. Angin meridional negative yang bergerak dari utara ke selatan terjadi pada bulan November. Hal ini menunjukkan adanya lag +1 bulan, dimana angin ke selatan terjadi 1 bulan lebih awal dibanding musim hujan yang jatuh di bulan Desember.

\subsection{Periode La Nina Kuat}

Analisis pola angin zonal dan meridional terhadap Indeks ONI (Oceanic Nino Index) pada tahun 2010 dilakukan di Palembang.

Berkebalikan dengan El Nino, pada saat ONI bernilai negatif berarti suhu muka laut di Pasifik timur lebih tinggi dari suhu muka laut di Pasifik tengah. Jika ONI negatif ini berada pada rentang -0,5 hingga -1,0 maka dinyatakan sebagai La Nina lemah. La Nina kategori sedang terjadi pada indeks -1 hingga $-1,5$, sedangkan LaNina kuat terjadi pada indeks $-1,5$ hingga -2,0. La Nina sangat kuat terjadi jika indeks ONI melebihi -2,0.

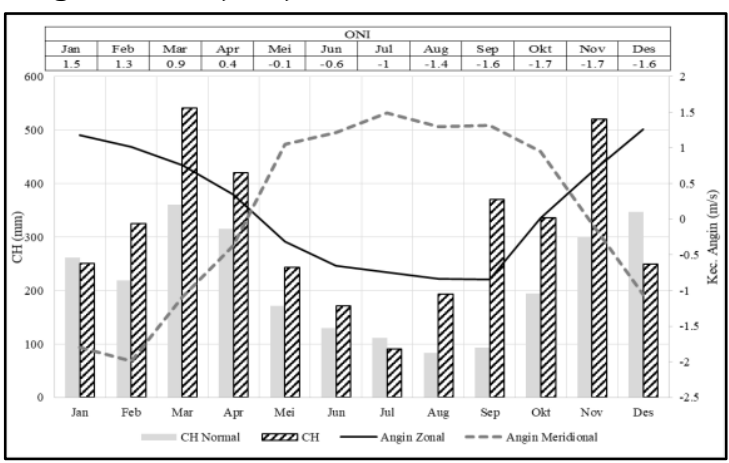

Gambar 3. Angin Zonal dan Meridional dan Curah Hujan Bulanan pada Periode La Nina Kuat (2010)

Indeks ONI pada tahun 2010 berada pada rentang -1,7-1,5 dengan indeks terendah pada bulan Oktober dan November dan Indeks tertinggi pada bulan Januari. Nilai minimum ONI yaitu -1,7 menunjukkan terjadinya kejadian La Nina kuat pada tahun ini. Respon curah hujan terhadap indeks ONI menunjukkan adanya peningkatan curah hujan terhadap periode normal utamanya di bulan Mei hingga November yaitu pada fase La Nina kuat. Peningkatan tertinggi terjadi di bulan November yaitu sebesar $520 \mathrm{~mm}$, yang terjadi pada fase La Nina Kuat.

Pola angin zonal pada tahun 2010 mencapai kecepatan maksimum pada bulan Desember sebesar $1,25 \mathrm{~m} / \mathrm{s}$ dan kecepatan minimum terjadi pada bulan Oktober sebesar
0,019 m/s. Pergerakan angin timuran dimulai pada bulan Mei dan berlangsung hingga bulan September. Hal ini mengindikasikan aktifnya angin monsoon timur yang membawa musim kemarau. Meskipun demikian, berdasarkan pada kriteria awal musim dari BMKG, Palembang tidak mengalami musim kemarau dikarenakan pengaruh dari kejadian La-Nina kuat yang meningkatkan curah hujan di Indonesia. Angin baratan mulai tampak di bulan Oktober yang memperkuat pengaruh La-Nina di Palembang, sehingga mengakibatkan peningkatan curah hujan dibanding periode normalnya.

Pola angin meridional pada tahun 2010 mencapai kecepatan maksimum pada bulan Februari sebesar 1,99 m/s dan kecepatan minimum terjadi pada bulan November sebesar $0,06 \mathrm{~m} / \mathrm{s}$. Angin meridional positif yang bergerak dari selatan ke utara terjadi pada periode bulan Mei hingga Oktober. Angin meridional positif tidak mempengaruhi jumlah curah hujan pada musim kemarau di Palembang akibat adanya fenomena La Nina. Angin meridional negative yang bergerak dari utara ke selatan terjadi pada periode November. Angin meridional negative ini ikut mempengaruhi jumlah curah hujan selain LaNina kuat yang sedang terjadi, sehingga jumlah curah hujan melebihi jumlah curah hujan ratarata normal.

\subsection{Periode IOD (+)}

Analisis pola angin zonal dan meridional terhadap fase IOD + dilakukan untuk tahun 1994. Fase IOD + merupakan kondisi dimana anomali suhu muka laut di Samudera Hindia bagian barat mengalami penghangatan, sedangkan di bagian timur mengalami pendinginan terhadap kondisi normal. Fase IOD + berpotensi mengurangi curah hujan di wilayah Indonesia (As-syakur dkk., 2014; dalam Avia dkk., 2018).

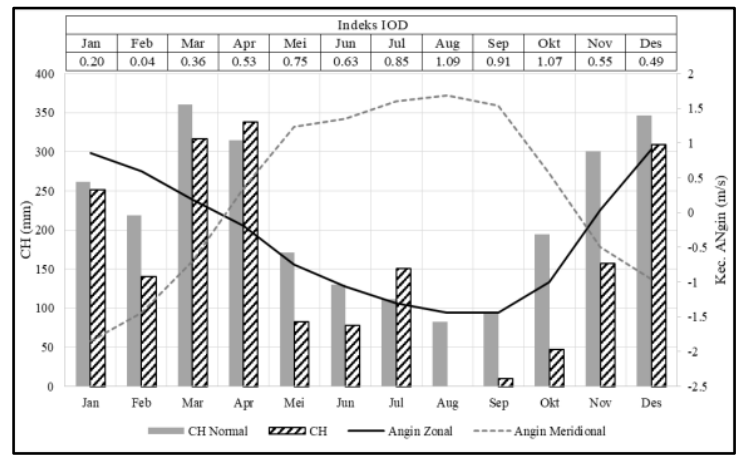

Gambar 4. Angin Zonal dan Meridional dan Curah Hujan Bulanan pada Periode IOD (+) 
Indeks IOD pada tahun 1994 berada pada rentang 0,035 - 1,09, dengan indeks terendah pada bulan Februari dan Indeks tertinggi pada bulan Agustus. Respon curah hujan terhadap indeks IOD menunjukkan adanya penurunan curah hujan terhadap periode normal di semua bulan kecuali bulan April dan Juli. Indeks IOD pada bulan April dan Juli menunjukkan nilai yang cukup tinggi yaitu 0,53 dan 0,85. Ketika indeks IOD mencapai nilai maksimum, terjadi penurunan curah hujan hingga mencapai $0 \mathrm{~mm}$ yang terjadi di bulan Agustus.

Pola angin zonal pada periode tahun 1994 menunjukkan pergerakan angin timuran yang dimulai pada bulan April dan berlangsung hingga bulan November. Hal ini mengindikasikan aktifnya angin monsoon timur yang membawa musim kemarau. Meskipun demikian, berdasarkan pada kriteria awal musim dari BMKG, wilayah Palembang mengalami musim kemarau di bulan Mei hingga Oktober. Hal ini menunjukkan adanya lag +1 bulan antara respon curah hujan terhadap angin zonal di Palembang. Angin baratan mulai tampak di bulan November dengan puncak kecepatan pada bulan Desember. Hal ini diikuti dengan awal musim hujan di bulan November yang tidak menunjukkan adanya lag.

Pola angin meridional pada periode tahun 1994 menunjukkan pola yang berkebalikan dengan angin zonal atau dapat dikatakan angin meridional negatif terjadi saat periode angin zonal positif dan sebaliknya. Angin meridional positif yang bergerak dari selatan ke utara terjadi pada periiode bulan April hingga November. Hal ini menunjukkan adanya lag+1 terhadap awal musim kemarau yang jatuh pada bulan Mei. Angin meridional negative yang bergerak dari utara ke selatan terjadi pada bulan November, yang diikuti dengan awal musim hujan pada bulan November.

\subsection{Periode IOD (-)}

Analisis fase IOD (-) dilakukan di Palembang untuk tahun 1996. Fase IOD (-) merupakan suatu pola yang berbanding terbalik dengan IOD (+). Fase IOD (-) ditandai dengan menghangatnya Samudera Hindia bagian timur yang diikuti dengan pendinginan Samudera Hindia bagian barat. Fase ini dapat mendukung penurunan curah hujan di wilayah Indonesia secara umum.

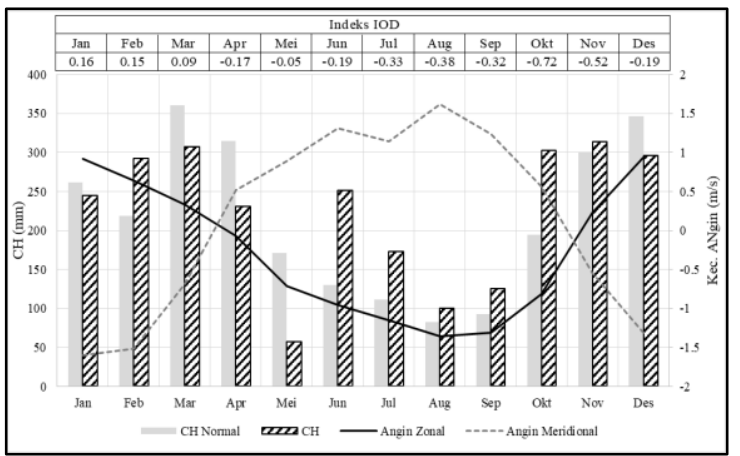

Gambar 5. Angin Zonal dan Meridional dan Curah Hujan Bulanan pada Periode IOD (-)

(1996)

Indeks IOD negatif pada tahun 1996 berada pada rentang -0,722 sampai - 0.16, dengan indeks terendah pada bulan Oktober dan Indeks tertinggi pada bulan Januari. Respon curah hujan terhadap indeks IOD menunjukkan adanya peningkatan curah hujan terhadap periode normal utamanya saat indeks IOD bernilai negatif, yaitu pada bulan Juni hingga November. Pada saat indeks IOD telah mencapai nilai terendah $-0,722$, terjadi peningkatan curah hujan sebesar $108 \mathrm{~mm}$ di bulan Oktober. Nilai ini masih berada di bawah bulan Juni yang mengalami peningkatan curah hujan hingga mencapai $121 \mathrm{~mm}$ dengan indeks IOD -0,185.

Pola angin zonal pada periode1996 menunjukkan pergerakan angin timuran yang dimulai pada bulan April dan berlangsung hingga bulan Oktober. Hal ini mengindikasikan aktifnya angin monsoon timur yang membawa musim kemarau. Meskipun demikian, berdasar pada kriteria awal musim dari BMKG, wilayah Palembang baru mengalami musim kemarau di bulan Agustus hingga September. curah hujan kurang dari $150 \mathrm{~mm}$ sudah terjadi di bulan Mei, namun terputus di bulan Juni dan Juli yang mengalami peningkatan curah hujan hingga mencapai $250 \mathrm{~mm}$ dan $180 \mathrm{~mm}$. Hal ini menunjukkan adanya pengaruh IOD (-) terhadap pengingkatan $\mathrm{CH}$ di wilayah Palembang, yang tidak diikuti perubahan pola angin zonal. Angin baratan mulai tampak di bulan November dengan puncak kecepatan pada bulan Desember. Hal ini diikuti dengan awal musim hujan di bulan Oktober hal ini menunjukkan musim hujan terjadi lebih dahulu dibanding angin baratan.

Pola angin meridional pada periode tahun 1996 menunjukkan pola yang berkebalikan dengan angin zonal atau dapat dikatakan angin 
meridional negative terjadi saat periode angin zonal positif dan sebaliknya. Angin meridional positif yang bergerak dari selatan ke utara terjadi pada bulan April hingga Oktober. Hal ini menunjukkan adanya lag+1 terhadap awal musim kemarau yang jatuh pada bulan Mei. Angin meridional negative yang bergerak dari utara ke selatan terjadi pada periode November, yang menunjukkan adanya lag -1 karena musim hujan yang dimulai lebih dahulu yaitu pada bulan Oktober.

\section{KESIMPULAN}

Awal musim hujan di Palembang tidak terlalu terpengaruh oleh angin zonal dan meridional lapisan $850 \mathrm{mb}$. Hal ini disebabkan karena awal musim hujan terjadi lebih dahulu dibanding perubahan arah angin. Atau dapat dikatakan bahwa terdapat mekanisme lain yang meningkatan uap air di atmosfer pada saat awal musim penghujan di Palembang. Awal musim kemarau lebih menunjukkan adanya pengaruh angin zonal dan meridional. Hal tersebut ditunjukkan oleh adanya lag antara perubahan arah angin dengan awal musim kemarau.

Pada periode El Nino, angin zonal dan meridional justru terlihat mempengaruhi awal musim di wilayah Palembang, utamanya awal musim hujan dimana pada periode normal justru tidak terlihat adanya pengaruh tersebut. Pada awal musim hujan, terlihat adanya lag satu bulan antara pergantian arah angin zonal dan meridional terhadap awal musim hujan di Palembang. Sedangkan pada periode IOD angin zonal dan meridional hanya terlihat mempengaruhi awal musim kemarau dengan memberikan lag satu hingga dua bulan terhadap awal musim kemarau.

Secara keseluruhan pengaruh angin zonal dan meridional di Palembang terhadap awal musim hanya terlihat pada awal musim kemarau. Pengaruh angin zonal dan meridional terhadap musim hujan justru terlihat pada saat periode El Nino. Apabila ditinjau lebih lanjut, pola perubahan angin zonal positif selalu konsisten di semua periode kecuali periode La Nina. Sementara pada periode El Nino awal musim hujan mengalami kemuduran. Sehingga adanya lag diantara keduanya disebabkan karena mundurnya musim kemarau, bukan karena pengaruh angin zonal dan meridional itu sendiri.

Adanya lag angin zonal dan meridional yang muncul terhadap awal musim kemarau dapat dijadikan prekursor awal musim kemarau di Palembang. Studi dengan penambahan periode ENSO maupun IOD sangat diperlukan untuk memperkuat hasil penelitian.

\section{UCAPAN TERIMA KASIH}

Ucapan terima kasih bersifat ditujukan kepada Stasiun Klimatologi Palembang dan pihak-pihak yang turut aktif dalam menyelesaikan penelitian ini.

\section{DAFTAR PUSTAKA}

Aldrian, E., Dümenil Gates, L., \& Widodo, F. H. (2007). Seasonal variability of Indonesian rainfall in ECHAM4 simulations and in the reanalyses: The role of ENSO. Theoretical and Applied Climatology. https://doi.org/10.1007/s00704-006-02188

Aldrian, E. (2008). Meteorologi Laut Indonesia. Jakarta: Badan Meteorologi dan Geofisika.

Allan, R., Lindesay, J., \& Parker, D. (1996). El Nino Southern Oscillation and climatic variability. In El Nino Southern Oscillation and climatic variability. https://doi.org/10.1111/j.17457939.1998.tb00534.x

As-syakur, A.R. (2012). Analisis Pola Spasial Hubungan Curah Hujan dengan ENSO dan IOD di Indonesia Melalui Observasi Data TRMM 3B43. Bunga Rampai Inderaja Indonesia Pusat Penginderaan Jauh Institut Teknologi Bandung (ITB). Cetakan 1, 92-107.

BMKG. (2013). Prakiraan Musim Hujan 2013/2014 di Indonesia. Jakarta:Badan Meteorologi Klimatologi dan Geofisika.

Hamada, J.I. (1995). Climatological Study on Rainfall Variation in Indonesia,(Master Thesis), Kyoto University: Kyoto

Harijanto, F. D., Kuntjoro, K., Saptarita, S., \& Aziz, S. K. (2012). Analisis Pola Hujan dan Musim di Jawa Timur Sebagai Langkah Awal Untuk Antisipasi Bencana Kekeringan. Jurnal Aplikasi Teknik Sipil. https://doi.org/10.12962/j12345678.v10i2 .2672

Harrison, D.E., Larkin, N.K. (1998). El Nino-Southern Oscillation Sea Surface Temperature and Wind Anomalies, 1946-1993. Reviews of Geophysics, 36, 3, 1998, 353-399.

Kato, S. dkk. (1998). Dinamika Atmosfer. Bandung: Penerbit ITB. 
Martono, M., \& Wardoyo, T. (2017). Impacts of El Niño 2015 and the Indian Ocean Dipole 2016 on Rainfall in the Pameungpeuk and Cilacap Regions. Forum Geografi. https://doi.org/10.23917/forgeo.v31i2.41

Power, S., Casey, T., Folland, C., Colman, A., \& Mehta, V. (1999). Inter-decadal modulation of the impact of ENSO on Australia. Climate Dynamics. https://doi.org/10.1007/s003820050284

Renggono, F. (2011). PENGARUH ENSO TERHADAP POLA ANGIN DAN CURAH HUJAN DI DAS LARONA, SULAWESI SELATAN. Jurnal Sains \& Teknologi Modifikasi Cuaca. https://doi.org/10.29122/jstmc.v12i2.2192

Ropelewski, C. F., \& Halpert, M. S. (1989). Precipitation Patterns Associated with the High Index Phase of the Southern Oscillation. Journal of Climate. https://doi.org/10.1175/15200442(1989)002<0268:ppawth>2.0.co;2
Saji, N. H., Goswami, B. N., Vinayachandran, P. N., \& Yamagata, T. (1999). A dipole mode in the tropical Indian ocean. Nature. https://doi.org/10.1038/43854

Sandy, L. M. (1987). Klimatologi Regional Indonesia. Depok: Jurusan Geografi FMIPA-UI.

Trenberth, K. E. (1997). The Definition of El Niño. Bulletin of the American Meteorological Society. https://doi.org/10.1175/15200477(1997)078<2771:TDOENO>2.0.CO;2

Ulfah, A., \& Sulistya, W. (2015). Penentuan Kriteria Musim Alternatif Di Wilayah Jawa Timur. Jurnal Meteorologi Dan Geofisika.

Yananto, A., \& Sibarani, R. M. (2016). ANALISIS KEJADIAN EL NINO DAN PENGARUHNYA TERHADAP INTENSITAS CURAH HUJAN DI WILAYAH JABODETABEK (Studi Kasus: Periode Puncak Musim Hujan Tahun 2015/2016). Jurnal Sains \& Teknologi Modifikasi Cuaca. https://doi.org/10.29122/jstmc.v17i2.541 